\title{
CARBOHYDRATES IN COLOBANTHUS QUITENSIS AND DESCHAMPSIA ANTARCTICA
}

\author{
AgNieszKa I. PiotrowiCZ-CieŚlAK ${ }^{1}$, IRENA GIEŁWANOWSKA ${ }^{1,2}$, \\ ANNA BOCHENEK ${ }^{1}$, PAWEŁ LORO ${ }^{2,3}$, RYSZARD J. GÓRECKI ${ }^{1}$ \\ ${ }^{1}$ Department of Plant Physiology and Biotechnology \\ University of Warmia and Mazury \\ Oczapowskiego 1A, 10-718 Olsztyn, Poland \\ e-mail: acieslak@uwm.edu.pl \\ 2 Department of Polar Biology \\ Ustrzycka 10/12, 02-141 Warszawa, Poland \\ ${ }^{3}$ Department of Botany and Nature Conservation \\ University of Warmia and Mazury \\ Plac Łódzki 1, 10-727 Olsztyn, Poland
}

(Received: November 2, 2004. Accepted: January 5, 2005)

\begin{abstract}
Eight to nineteen ethanol-soluble carbohydrate components were identified in vegetative tissues of Colobanthus quitensis and Deschampsia antarctica. The analysed carbohydrates included: monosaccharides, cyclitols, galactosyl cyclitols, raffinose family oligosaccharides, lichnose family oligosaccharides, kestose family oligosaccharides. The analysed vegetative tissues accumulated from 447 to $139 \mathrm{mg} / \mathrm{g} \mathrm{d} . \mathrm{m}$. soluble carbohydrates in Colobanthus quitensis, Deschampsia antarctica respectively. The raffinose family oligosaccharides constituted 53.3\% in Colobanthus quitensis of the identified soluble carbohydrate component pool. Vegetative tissues accumulated starch in Colobanthus quitensis $20.6 \mathrm{mg} / \mathrm{g} \mathrm{d} . \mathrm{m}$. and $261.6 \mathrm{mg} / \mathrm{g} \mathrm{d}$.m. in Deschampsia antarctica. Anatomical and ultrastructural observations of vegetative part of Colobanthus quitensis and Deschmpsia antarctica revealed the presence of various ergastic materials in intercellular spaces, cell walls and protoplasts. Various parts of these plants contain insoluble, PAS positive polysaccharides in intercellular spaces and in cell walls. Chloroplasts of analysed tissues contained starch. Less starch was visible in young, growing parts of shoots of Colobanthus quitensis and Deschmpsia antarctica, more starch appears in mature, differentiated parts.
\end{abstract}

KEY WORDS: Colobanthus quitensis, Deschmpsia antarctica, soluble sugars, starch.

\section{INTRODUCTION}

Plants have to be able to cope with severe abiotic stresses, caused by low temperature, repeated freezing and thawing, repeated desiccation, high irradiance and salinity (Alberdi et al. 2002). The acquisition of abiotic stress resistance by plants and seeds depends on chemical substances preventing adverse effects stress. Colobanthus quitensis (Kunth) Bartl. and Deschmpsia antarctica Desv. are the only two angiosperm plants that have colonized the Maritime Antarctic (Komarkova et al. 1990). The major stress factors they have to face there are temperature and hydration, because the region has a cold and moist maritime climate. Even during the austral summer, mean monthly temperatures are near $2^{\circ} \mathrm{C}$ and often fall below $0^{\circ} \mathrm{C}$ (RakusaSuszczewski et al. 1992). Acclimation to cold occurs by gradual adaptation to low temperature and involves a genetically programmed process that includes the synthesis of such compounds as proteins, lipids and soluble carbohydrates (Alberdi, Corcuera 1991). Soluble carbohydrates accumulating at low temperatures may have the dual function of storing carbon and providing cryoprotectants (Bachmann et al. 1994). In grasses, large amounts of fructans are accumulated during cold seasons (Pollock, Cairns 1991). Similar to vacuolar fructans, raffinose family oligosaccharides (RFOs) are known to increase during cold acclimation in vegetative tissues (Castonguay, Nadeau 1998). Raffinose provides protection for biomembranes and proteins by acting as a compatible solute (Yancey et al. 1982). RFOs solutions may promote transition of cellular contents to the vitreous (glassy) state that protects macromolecular structures during seed desiccation (Leopold et al. 1994). 
RFOs may also directly stabilize membranes by replacing water molecules between the polar headgroups of phospholipids (Crowe et al. 1996). Accumulation of cyclitols (cyclic polyols) and their methylated derivatives is correlated with desiccation and salinity tolerance (Bohnert et al 1995). Cyclitols seem to function in two ways that are difficult to separate mechanistically: osmotic adjustment and osmoprotection. In osmotic adjustment, they act as osmolytes, facilitating the retention of water in the cytoplasm and allowing sodium sequestration to the vacuole and/or apoplast. Alternatively, protection of cellular structures (possibly by scavenging active oxygen) might be accomplished through interactions of such osmolytes. Their osmoprotective function in cytosol may be related to their unique chemistry. Those cyclitols, that are non-reducing sugars, may also store excess carbon under environmental stress conditions (Paul, Cockburn 1989; Popp et al. 1997).

The aim of this study was to determine the qualitative and quantitative composition of soluble and unsoluble sugars in the tissues of Antarctic plants.

\section{MATERIAL AND METHODS}

\section{Plant material}

Above-ground parts of Colobanthus quitensis (Caryophyllaceae) and Deschampsia antarctica (Poaceae) were used in experiments. Fresh material was collected from na- tural stands near Polish Antarctic H. Arctowski Station on King George Island (South Shetland Islands) during the $26^{\text {th }}$ Antarctic expedition organized by the Polish Academy of Sciences (in January 2002, about 11 a.m.). Microscope slides were prepared using fresh vegetative tissues whereas the carbohydrate contents were determined in dry material.

\section{Light and electron microscopy}

Leaf pieces, 2-3 mm long, were fixed in 3.5\% glutaraldehyde in $0.1 \mathrm{M}$ phosphate buffer $(\mathrm{pH} \mathrm{7.0)}$ ) for $10 \mathrm{~h}$ at room temperature. Fixed tissue was washed in two exchanges of $0.1 \mathrm{M}$ phosphate buffer and postfixed over night in $2.5 \%$ $\mathrm{OsO}_{4}$. The tissue was then washed in buffer, dehydrated in a graded ethanol series, transferred to mixtures with increasing ratios of Poly Bed 812 resin, and finally embedded in pure Poly Bed 812 resin. Semithin sections (1-2 $\mu \mathrm{m})$ were stained with toluidine blue and viewed with a light microscope. Ultrathin sections were stained with uranyl acetate and lead citrate (Reynolds 1963) and observed with a JEOL Jem 100S transmission electron microscope (TEM).

\section{PAS reaction}

Plant samples were fixed in a mixture of ethyl alcohol and acetic acid $(3: 1)$. The specimens were stained in toto with periodic acid and Schiff reagent for insoluble polysaccharides (Pearse 1972). The tissue, after dehydration, was embedded in Poly Bed 812 resin. Semithin sections (1-2 $\mu \mathrm{m})$ were viewed with a light microscope.
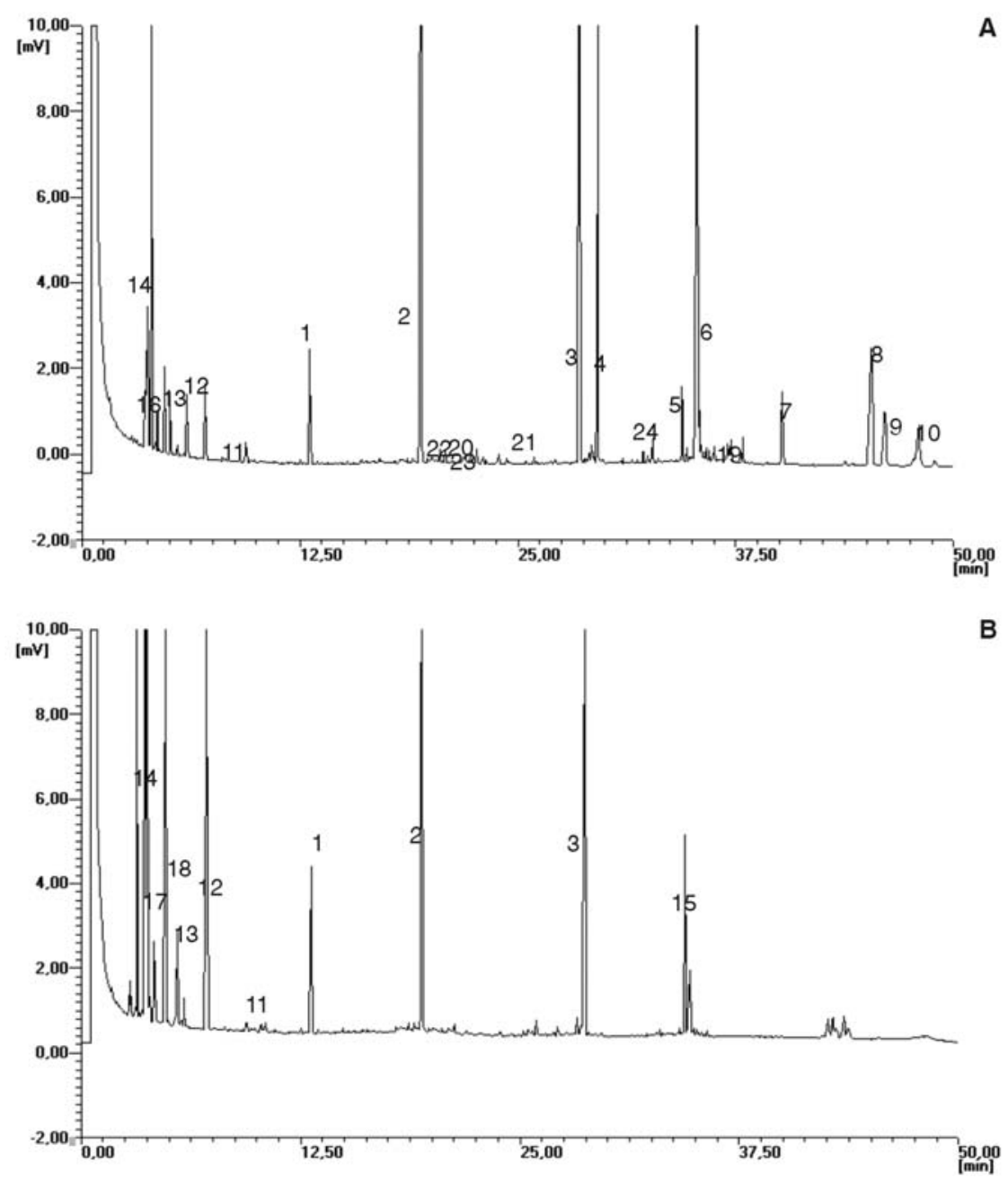

Fig. 1. Chromatogram of soluble carbohydrates isolated from Colobanthus quitensis (A) and Deschampsia antarctica (B).

Peaks: 1 - internal standard; 2 - sucrose; 3 raffinose; 4 - lichnose; 5 - digalacto-myoinositol; 6 - stachyose; 7 - trigalactopinitol B; 8 - unknown; 9 - verbascose; 10 unknown; 11 - myo-inositol; 12 - glucose; 13 - ononitol; 14 - D-pinitol; 15 - 1.1kestotetrose; 16 - fructose; 17 - galactose; 18 - glucose; 19 - trigalactopinitol A; 20 galactinol; 21 - galactoononitol; 22 - galactopinitol B; 23 - galactopinitol; 24 - isolichnose 


\section{Carbohydrate extraction and analysis}

Cyclitols, galactosyl cyclitols and soluble sugars contents were analyzed according to the method of Górecki et al. (1997). Dry and fresh tissue mass were also examined. $30 \mathrm{mg}$ of tissue were homogenized in ethanol: water, 1:1 $(\mathrm{v} / \mathrm{v})$ containing $100 \mu \mathrm{g}$ phenyl- $\alpha$-D-glucose as internal standard (Horbowicz, Obendorf 1994). The homogenate and the rinse were combined in a $1.5-\mathrm{ml}$ microfuge tube, heated at $75^{\circ} \mathrm{C}$ for $30 \mathrm{~min}$ to inactivate endogenous enzymes and centrifuged at $15000 \mathrm{~g}$ for $20 \mathrm{~min}$. The supernatant was passed through a $10000 \mathrm{MW}$ cut-off filter (Lida, Kenosha, WI USA). Aliquots of $0.5 \mathrm{ml}$ filtrate were transferred to silylation vials and evaporated to dryness under a stream nitrogen. Residues were kept overnight in a desiccator, over phosphorus pentoxide. Dry residues were derived with $300 \mu \mathrm{l}$ of silylation mixture (trimethylsilylimidazole: pyridyne, 1:1, v/v) in silylation vials (Supelco) at $70^{\circ} \mathrm{C}$ for $30 \mathrm{~min}$ and then cooled at room temperature. One $\mu l$ of carbohydrates was injected into a split-mode injector of a Shimadzu GC-14A gas chromatograf equipped with flame ionization detector and Shimadzu C-R6A integrator. Soluble carbohydrate were analysed on a DB-1 capillary column (15 m lengh, $0.25 \mathrm{~mm}$ ID, $0.25 \mu \mathrm{m}$ film thickness, J\&W Scientific) operated with a programmed initial temperature of $150^{\circ} \mathrm{C}$, adjusted to $200^{\circ} \mathrm{C}$ at $3^{\circ} \mathrm{C} / \mathrm{min}$, adjusted $325^{\circ} \mathrm{C}$ at $7^{\circ} \mathrm{C} / \mathrm{min}$, and held $325^{\circ} \mathrm{C}$ for $40 \mathrm{~min}$ the injector port was at $335^{\circ} \mathrm{C}$ and the detector at $350^{\circ} \mathrm{C}$. The carrier gas was helium at $3 \mathrm{ml} / \mathrm{min}$, split 1:50 and the detector gases were hydrogen at $30 \mathrm{ml} / \mathrm{min}$ and air at $300 \mathrm{ml} / \mathrm{min}$. Soluble carbohydrates were identified with internal standards as available and calculated from the ratios of peak area for each analysed carbohydrate to the peak area of respective internal standard.

Quantities of soluble carbohydrates were expressed as mean \pm SD for 3-5 replications of each treatment.

Starch content in above-ground parts of plants was measured by enzymatic test (Boehringer) based on the UV-method for determination of native starch (Beutler 1984).

\section{Carbohydrate and cyclitol standards}

Glucose, fructose, sucrose, raffinose, stachyose, myoinosytol and internal standard (phenyl- $\alpha-D$ glucopiranoside) were purchased from Sigma Chemical Company. 1.1-kestotetrose was purchased from Megazyme (Ireland), lichnose, isolichnose were isolated from Lychnis dioica, verbascose was isolated from Vicia faba bean, galactinol was purchased from Waco (Japan), digalactol-myo-inositol, galactoononitol, digalactoononitol, galactopinitol, digalactopinitol B, trigalactopinitol B were a gift from Vactim Laboratory (USA) and ononitol D-pinitol, D-chiro-inositol were purchased from Industrial Research (Japan).

\section{RESULTS}

\section{Carbohydrate content}

Twenty one carbohydrate components were identified in vegetative tissues, including: monosaccharides, disaccharides, cyclitols, galactosyl cyclitols, raffinose family oligosaccharides, kestose family oligosaccharides and a polysaccharide - starch. More chemical species were found in $\mathrm{Co}$ lobanthus quitensis (20) than in Deschampsia antarctica
(9). The tissues of Antarctic plants contain 14 and $45 \%$ d.m. of soluble sugars and 2 and $24 \%$ d.m. of sum of RFOs in Deschampsia antarctica and Colobanthus quitensis, respectively. Sucrose was found to be the major carbohydrate in $C$. quitensis but starch content was low. Raffinose was found to be the major soluble carbohydrate in D. antarctica but starch content was the highest (26\%) of all carbohydrates (Table 1). Soluble carbohydrates of Colobanthus quitensis tissues included lychnose, isolychnose, glucose, fructose, galactose, sucrose, D-pinitol, ononitol, myo-inositol, raffinose, stachyose, verbascose galactinol, digalactomyo-inositol B, digalactopinitol B, trigalactopinitol B (Figs 1A, 4A, 4B). Soluble carbohydrates of Deschampsia antarctica tissues were composed of 1.1-kestotetrose, raffinose, sucrose, fructose, glucose, galactose, galactinol and myo-inositol (Fig. 1B, 4A, 4B).

\section{Microscopic studies}

Anatomical and ultrastructural observations of Colobanthus quitensis and Deschampsia antarctica revealed the presence of various ergastic materials in intercellular spaces, cell walls and protoplasts.

Various parts of Colobanthus and Deschampsia shoots contain insoluble, PAS positive polysaccharides, visible on light microscope semithin slides in intercellular spaces (Figs 2A, C-E, Fig. 3E, arrows and arrow heads) and in cell walls. Chloroplasts of analysed tissues contained starch, showing as light grains (Figs 2B - Sg, Fig. 3B-D $\mathrm{Sg}$ ) or dark grains (Fig. $2 \mathrm{~F}-\mathrm{Sg}$ ).

Less starch was visible in young, growing parts of shoots (Fig. 2A - Sg, Fig. 3A), where the grains are concentrated mainly around the vascular bands. More starch appears in mature, differentiated parts (Fig. 2F - Sg, Fig. 3E - Sg) yellowing leaves and bracts (Fig. 2B - Sg). Starch can be seen in chloroplasts in all parts of Colobanthus and Deschampsia shoots, including the stele (Fig. $2 \mathrm{~F}-\mathrm{Sg}$ ).

In addition to starch-containing chloroplasts, many single or coalescing droplets of osmophilic material, can be seen in the mesophyll cells of both Antarctic plants (D, Fig. 2F, Figs 3B, D, F). A similar material is visible in intercellular spaces in $C$. quitensis stele (Fig. 2F).

In the cytoplasm of leaf mesophyll cells of Colobanthus and Deschampsia abundant electron transparent or electron dense vesicles could often be observed, as well as multivesicle bodies (Fig. 3B, arrows, arrow heads). In direct vicinity of such bodies droplets containing dense osmophilic material can also be seen.

\section{DISCUSSION}

Antarctic vascular plants can withstand low air temperatures by colonizing the most adequate microhabitats and on the other hand by specific metabolic adaptations, particularly during the growth season, when most other plants are vulnarable to coldness. Bravo et al. (2001) have shown that Deschampsia antarctica is highly freeze-tolerant even during the austral summer. To function at low temperatures plants must have membranes with sufficient fluidity, without which normal metabolism would not be possible. The studies by Zúniga et al. (1994, 1996) have shown however, that under natural conditions the unsaturation level of fatty acids in D. antarctica membranes is comparable to 

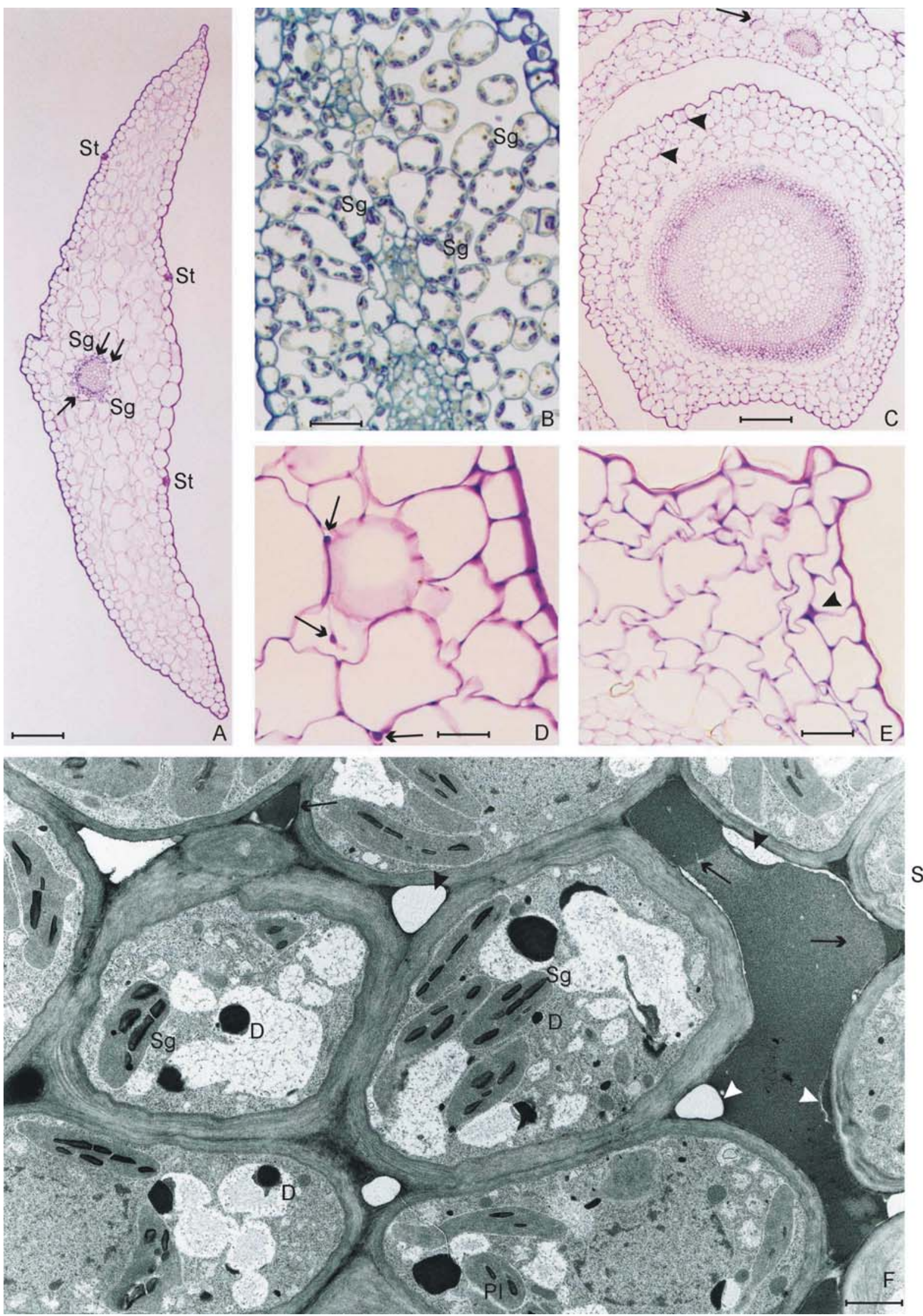

Fig. 2. Ergastic materials in different parts of Colobanthus quitensis. A - PAS - positive materials visible in cell walls and intercellular spaces (arrows) on a leaf blade cross section. Bar $=100 \mu \mathrm{m} ; \mathrm{B}-$ Starch - containing chloroplasts in a leaf mesophyll cell. A semi-thin section stained in toluidine blue. Bar $=$ $30 \mu \mathrm{m}$; C - C-E. Insoluble polysaccharides of cell walls and intercellular spaces, stained in a PAS reaction, in cross sections of stem (C, E) and leaf sheath (C, D). PAS positive materials accumulate, forming larger or smaller droplets, adjoining cell walls (arrows) or completely filling the intercellular spaces (arrow heads). Semi-thin sections; C - Bar $=100 \mu \mathrm{m}, \mathrm{D}$ and E - Bars $=25 \mu \mathrm{m} ; \mathrm{D}-$ Part of stem stele with intercellular spaces filled with granular-fibrillar, osmophilic material, with areas of different densities (arrows). Areas free of this material (arrow heads) can also be seen inside the intercellular spaces. Large deposits of condensing starch can be seen in chloroplast stroma. Osmophilic material (D) can be seen in the cytoplasm, bordering on chloroplasts, and in vacuolar compartments. Bar $=4 \mu \mathrm{m}$. 

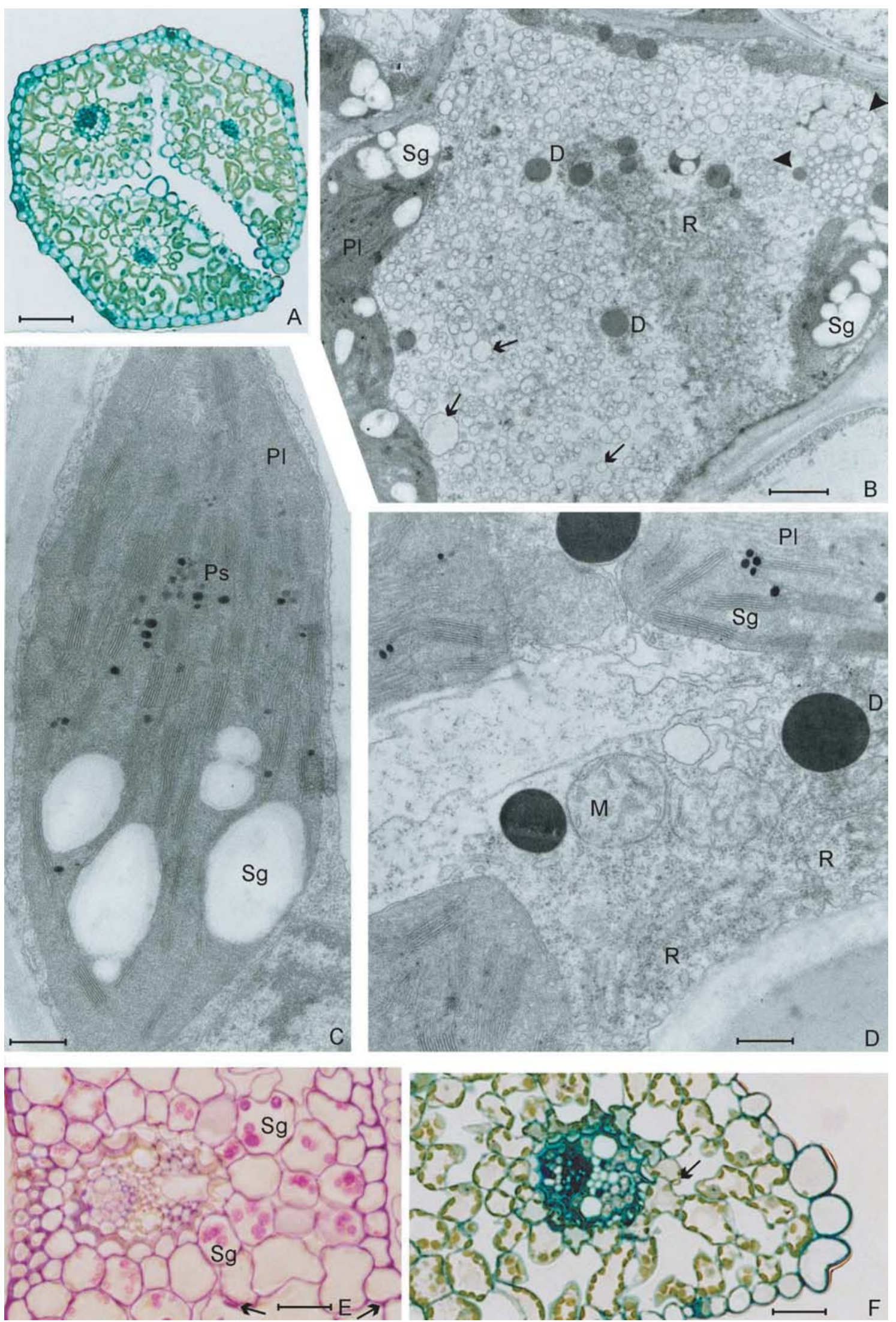

Fig. 3. Ergastic materials in cells of Dechampsia antarctica mesophyll. A - Anatomy of trinervate leaf of Dechampsia antarctica. Note thick abaxial epiderm, undifferentiated mesophyll and adaxial epiderm with stomata. All mesophyll cells contain chloroplasts. Semi-thin section was stained with toluidine blue. Bar $=100 \mu \mathrm{m} ; \mathrm{B}-$ Mesophyll cell with chloroplasts $(\mathrm{Pl})$, starch $(\mathrm{Sg})$, great number of differentiated vesicles (arrows) and multivesicular bodies (arrow heads). Osmophilic droplets (D) can be seen in the cytoplasm, among starch containing chloroplasts and in the vicinity of ribosomal aggregates $(\mathrm{R})$. Bar $=2 \mu \mathrm{m} ; \mathrm{C}-$ Chloroplast (Pl) with starch grains (Sg) and lipid plastoglobules (Ps). Bar $=0.5 \mu \mathrm{m} ; \mathrm{D}-\mathrm{A}$ fragment of mesophyll cell cytoplasm. Osmophilic droplets (D) appear close to chloroplasts $(\mathrm{Pl})$ and mitochondria $(\mathrm{M})$ and ribosomal aggregates $(\mathrm{R})$. Bar $=0.5 \mu \mathrm{m} ; \mathrm{E}-\mathrm{PAS}$-positive materials in a mesophyll cell of $D$. antarctica. Insoluble polysaccharides appear in intercellular spaces (arrows) and within cell walls. Large amounts of starch ( $\mathrm{Sg}$ ) are visible in chloroplasts of cells neighbouring on leaf bundles (parenchymatous bundle sheath and around the sheath). Bar $=30 \mu \mathrm{m} ; \mathrm{F}-$ Fragment of a leaf blade with central leaf bundle. Chloroplasts, containing starch grains ( (arrows) ), are visible in mesophyll cells. Semi-thin section was stained with toluidine blue. Bar $=30 \mu \mathrm{m}$. 
TABLE 1. Carbohydrates composition in the vegetative tissues of Colobanthus quitensis and Deschampsia antarctica [mg per g d.m. tissues] (data are the means of 3-5 replications \pm standard deviation).

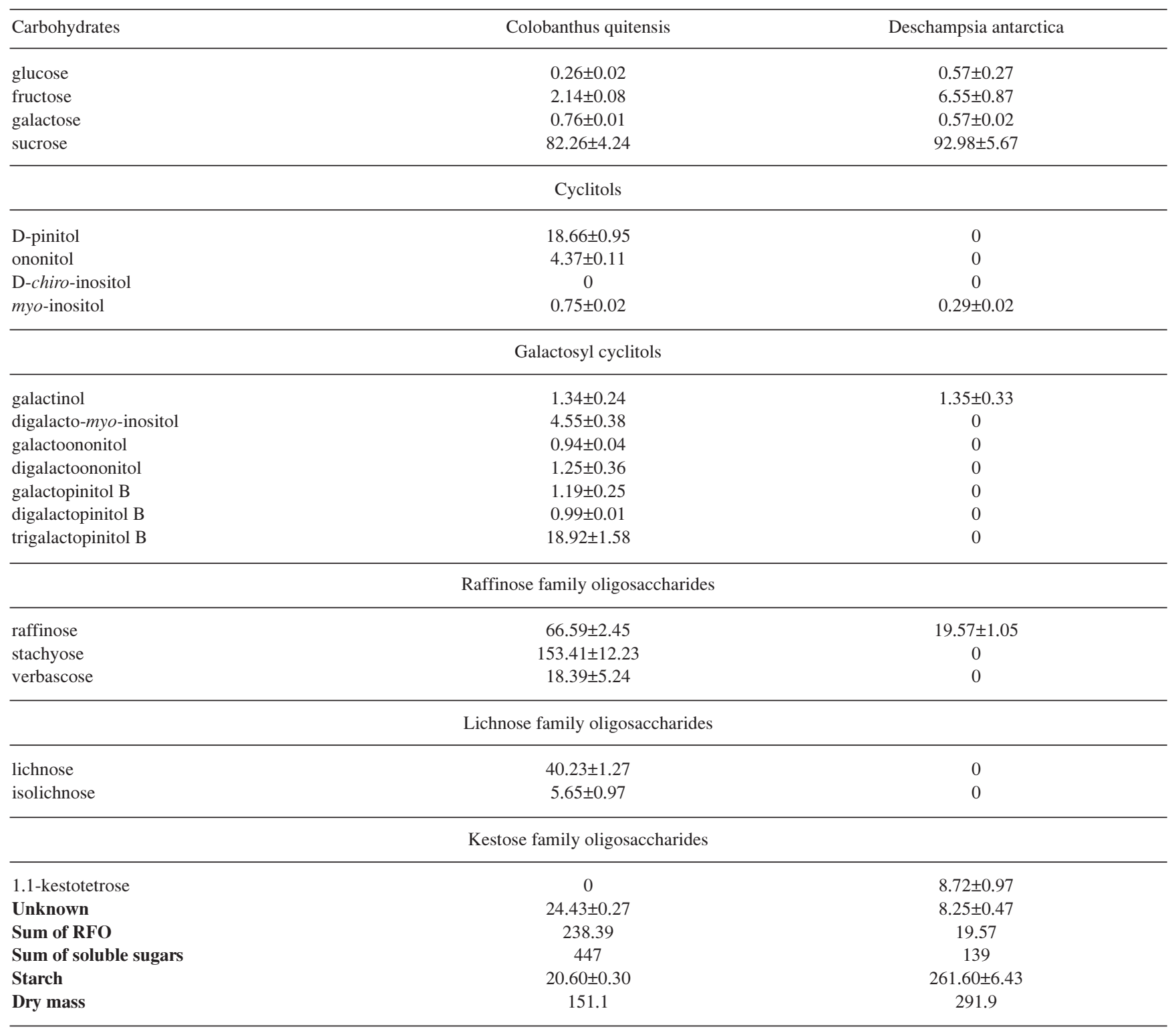

that of other grasses while the soluble carbohydrates level is higher than in cereals. Alberdi et al. (2002) suggested that carbohydrate accumulation could be related to enhanced freezing tolerance of this species. Our observations support this hypothesis and it seems even more true for Colobanthus quitensis. During summer the latter species accumulates three times more soluble carbohydrates than Deschampsia.

Colobanthus quitensis contains oliogosaccharides of raffinose family series (raffinose, stachyose, verbascose) together with lychnose and isolychnose in the above-ground part of plant. The lychnose tetrasaccharide was discovered in roots of Lychnis dioica. Lychnose, isolychnose and and their high homologues are common in all vegetative parts of Lychnis dioica and other species of Caryophyllaceae, but they are not being found in seeds (Kandler, Hopf 1980). Therefore, lychnose and isolychnose series may be useful as a chemotaxonomic marker. In vegetative tissues of $C$. quitensis the content of soluble carbohydrates is comparable to the content of sugars stored in seeds. It is supposed that due to a high soluble carbohydrate content the plants are more resistant to abiotic stresses. Soluble sugars protect cellular membranes, enzymatic proteins and other macromolecules against physical destruction during dehydration (Crowe, Crowe 1992). Biosynthesis of oligosaccharides in seeds lowers the content of reducing monosaccharides (Dey, 1985). Low levels of fructose, glucose and galactose limit the intensity of the Amadori-Maillard reaction (Wettlaufer, Leopold 1991).

A positive correlation between the levels of fructans and freezing tolerance of grasses has also been demonstrated (Pollock et al. 1989; Suzuki 1989). The accumulation of soluble sugars can improve survival rate of Antarctic plants by providing a source of readily available energy during the period of negative carbon balance. In Zuniga's studies (1996) the level of soluble sugars in January was similar to the values reported here, while it increased distinctly in February. This observation supports the hypothesis that resources of readily available metabolic energy are being accumulated before winter. Undoubtedly, these sugars can also serve as cryoprotectants. Fructans (polyfructosylsucrose) consist of polymers of fructose attached to sucrose and se- 


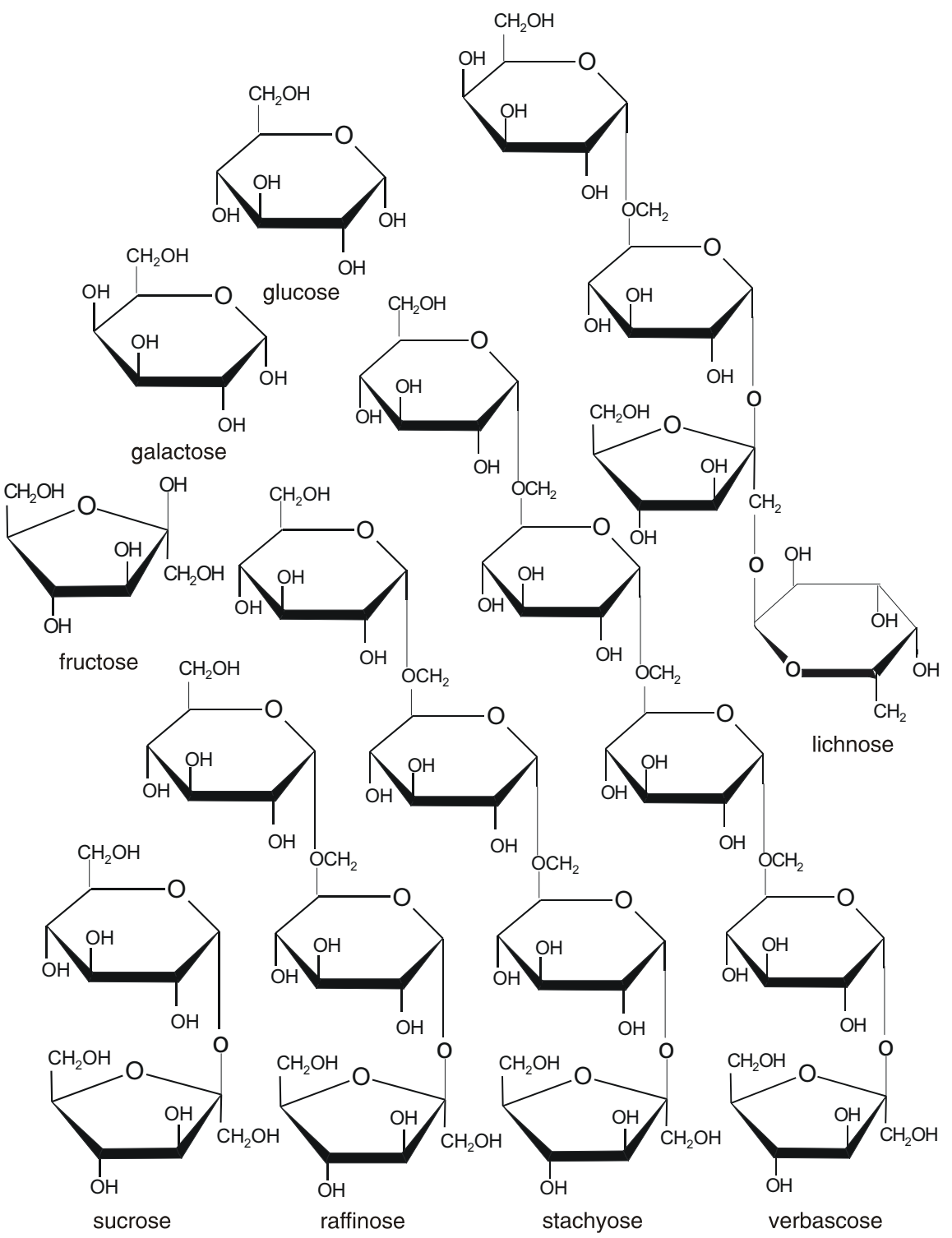

Fig. 4A. Mono- and oligosaccharides in Deschampsia antarctica and Colobanthus quitensis vegetative tissues. rve as an important storage carbohydrate in approximatetely $15 \%$ of flowering plant species (Hendry, Wallace 1993). In most grasses branched fructans containing both types of linkages are produced (e.g. Triticum aestivum L.; Carpita et al. 1989). Fructatans are fructose based oligo- or polysaccharides. The precise type and the degree polymerization (DP) are species- and even tissue specific. Inulin type fructans consist of linear $\beta(2 \rightarrow 1)$-linked fructofuranosyl units and occur in dicotyledonous species such as Cichorium intybus, Helianthus tuberosus, and Taraxacum officinale. Monocotyledonous species often contain levans consisting of linear $\beta(2 \rightarrow 6)$-linked fructofuranosyl units at more complex branched graminans (Shiomi 1989; Livingston et al. 1993; Vijn et al. 1997). Aside from a function as a long- or shortterm reserve carbohydrate, other, perhaps more specific roles in plants remain elusive; however, data suggest a correlation with drought and/or frost tolerance (Hendry 1993; Pilon-Smith et al. 1995; Livingston, Henson 1998).

The oligosaccharides with a low degree of polymerization are then accumulated as cryoprotectants. This is probably the role of 1,1-kestotetrose, identified in Deschampsia.

Zúniga et al. (1996) and Bravo et al. (2001) did not study the presence of RFOs, cyclitols and galactosylocyclitols in tissues of vascular Antarctic plants, but focussed on determinations of fructans, sucrose and monosaccharides, which resulted from the methods applied. In this paper we report sucrose contents similar to observed by those authors, while the levels of fructans in D. antarctica were distinctly lower. C. quittens, like other Caryophyllaceae did not contain any fructans. Oligosaccharides of the raffinose family dominated in this species. Similar levels of RFOs were reportedly found in Ajuga reptans, a species easily undergoing cold acclimation (Bachmann et al. 1994). In both theses species RFOs may probably replace starch as carbon reserve. Warm-climate plants, like pumpkin, contain lower levels of RFOs than A. reptans and C. quitensis. The raffinose preponderance to bind to proteins and membranes and exert thus a protective action have been well established. According to Bachmann and Keller (1995) RFOs in A. reptans, particularly those with higher polymerization level, are partially locallised in vacuoles where they can play the role of storage materials and osmoregulatory factors. They are also partially localized in cytosol, where they can serve as cryoprotectants.

Low temperature is known to stimulate the activity of galactinol synthase (GAS), whereas galactinol is a substra- 


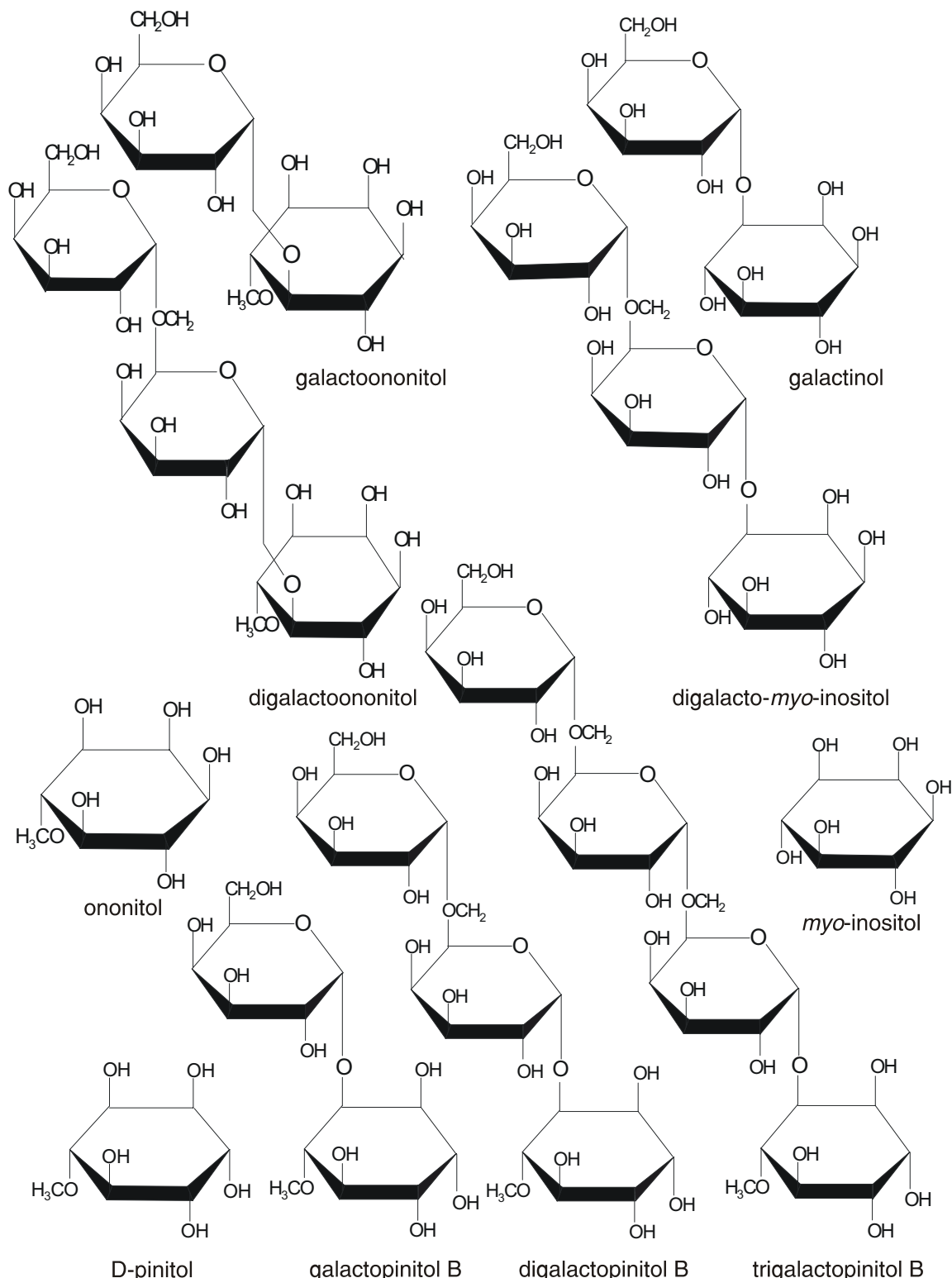

Fig. 4B. Cyclitols and galactosyl cyclitols in Deschampsia antarctica and Colobanthus quitensis vegetative tissues. te necessary for raffinose and stachyose formation (Castillo et al. 1990). Accumulation of RFOs can also be affected by the level of myo-inositol, which is a substrate for galactinol biosynthesis (Keller et al. 1998). Both these cyclic alcohols have been found in both species studied. Colobanthus contains furthermore many other cyclitols and galactosylocyclitols, which may act as osmoprotective agents and cryoprotectants. They could also be used as chemotaxonomic markers for this species.

Starch content in tissues of $C$. quitensis was relatively low, still it was twice as high as reported by Bravo et al. (2001) and comparable to the level found in A. reptans (Bachman et al. 1994). Microscopic analyses have shown that it was localized in chloroplasts only. The starch grains had an interesting appearance - regular arrangements of rods, highly osmophilic, visible in electron microscope as dark areas within the chloroplasts. It seems that in plants collected during long summer days a particularly rapid concentration of starch occurred, as a result of intensive photosynthesis. It seems also interesting that in intercellular spaces an amorphic material accumulates, which is pro- bably composed of insoluble carbohydrates (PAS) reaction. It is possibly another way of setting up a carbon (assimilate) reserve, which will be used in autumn for cellular structures reconstruction, and synthesis of cryoprotectants. The level of starch in tissues of Deschampsia antarctica is very high, several fold higher than might be inferred from studies by Bravo et al. (2001), carried out under unnatural conditions. These data are corroborated by microphotographs, in which many chloroplasts can be seen, containing globular, typically shaped and coloured starch grains. The reason for the discrepancy with the published results may be in huge differences between the laboratory and natural conditions (strong winds, temperature fluctuations, light spectrum, salinity, etc.). In D. antarctica high starch content is accompanied by relatively low RFOs and fructans levels. No other PAS-positive materials, other than starch, could be seen in the microphotographs within the cell protoplasts. Abundant osmophilic, coalescing droplets may serve as carbon reserve, though in a form different from carbohydrates (as lipids or proteins). 


\section{LITERATURE CITED}

ALBERDI A., BRAVO L.A., GUTIERREZ A., GIDEKEL M., CORCUERA L.J. 2002. Ecophysiology of Antarctic vascular plants. Physiol. Plant. 115: 479-486.

ALBERDI A., CORCUERA L.J. 1991. Cold acclimation in plant. Phytochemistry 30: 3177-3184.

BACHMANN M., KELLER F. 1995. Metabolism of the raffinose family oligosaccharides in Ajuga reptans L. Plant. Physiol. 109: 991-998.

BACHMANN M., MATILE P., KELLER F. 1994. Metabolism of the raffinose family oligosaccharides in leaves of Ajuga reptans L. Plant. Physiol. 105: 1335-1345.

BEUTLER H.-O. 1984. In: Methods of Enzymatic Analysis. Ed. Bergmeyer H.U. Vol. VI: 11-18. Weinheim, Deerfield Beach/Florida, Basel, Verlag Chemie.

BOHNERT H.J., NELSON D.E., JANSEN R.G. 1995. Adaptation to environmental stresses. Plant. Cell. 7, 1099-1111.

BRAVO L.A., ULOA N., ZUNIGA G.E., CASANOVA A., CORCUERA L.J., ALBERDI M. 2001. Cold resistance in Antarctic angiosperms. Physiol. Plant. 111: 55-65.

CARPITA N.C., KANABUS J., HOUSLEY T.L. 1989. Linkage structure of fructans and fructan oligomers from Triticum aestivum and Festuca arundinaceae leaves. J. Plant. Physiol. 134: 162-168.

CASTILLO E.M., DE LUMEN B.O., REYES P.S., DE LUMEN H.Z. 1990. Raffinose synthase and galactinol synthase in developing seeds and leaves of legumes. J. Agric. Food Chem. 38: 351-355.

CASTONGUAY Y., NADEAU P. 1998. Enzymatic control of soluble carbohydrate accumulation in cold - acclimated crowns of alfalfa. Crop Sci. 38: 1183-1189.

CROWE J.H., HOEKSTRA F.A., NGUYEN K.H.N., CROWE L.M. 1996. Is vitrification involved in depression of the phase transition temperature in dry phospholipids? Biochim. Biophys. Acta 1280: 187-196.

CROWE L.M., CROWE J.H. 1992. Stabilization of dry liposomes by carbohydrates. In: Developments in biological standarization, (eds) May J.C., Brown F., Basel S., Karger AG. Volume 74, Biological products free-drying and formulation, 313-363.

DEY P.M. 1985. D-galactose-containing oligosaccharides. In: Biochemistry of storage carbohydrates in green plants, (eds) Dey P.M., Dixon R.A. Academic Press, London, 53-129.

GÓRECKI R.J., PIOTROWICZ-CIEŚLAK A.I., OBENDORF R.L. 1997. Soluble sugars and flatulence-producing oligosaccharides in maturing yellow lupin (Lupinus luteus L.) seeds. Seed Sci. Res. 7: 185-193.

HENDRY G.A.F. 1993. Evolutionary origins and natural functions of fructans: a climatological, biogeographic and mechanistic appraisal. New Phytol. 123: 3-14.

HENDRY G.A.F., WALLACE R.K. 1993. The origin, distribution, and evolutionary significance of fructans. In: Science and Technology of Fructans, (eds) Suzuki M., Chatterton N.J. CRC Press, Boca Raton, FL, 119-139.

HORBOWICZ M., OBENDORF R.L. 1994. Seed desiccation tolerance and storability: dependence on flatulence-producing oligosaccharides and cyclitols - review and survey. Seed Sci. Res. 4: 385-405.

KANDLER O., HOPF H. 1980. Carbohydrates: Structure and Function. In: The Biochemistry of Plants, (eds) Stumpf P.K., Conn E.E. Academic Press. 221-270.

KELLER R., BEARLEY C.A., TRETHEWEY R.N., MULLERROBER B. 1998. Reduced inositol content and altered morphology in transgenic potato plants inhibited for 1D-myo-inositol 3-phosphate synthase. Plant. J. 16: 403-410.
KOMARKOWA V., PONCET S., PONCET J. 1990. Additional and revisited sites localistics of vascular plants Deschampsia antarctica Desv. and Colobanthus quitensis (Kunth) Bartl. in the Antarctic Penisula area. Arctic Alp. Res. 22: 108-113.

LEOPOLD A.C., SUN W.Q., BERNAL-LUGO I. 1994. The glassy state in seeds: analysis and function. Seed Sci. Res. 3: 267-274.

LIVINGSTON D.P., CHATTERTON N.J., HARRISON P.A. 1993. Structure and quantity of fructan oligomers in oat (Avena spp.). New Phytol. 123: 725-734.

LIVINGSTON D.P., HENSON C.A. 1998. Apoplastic sugars fructans fructan exohydrolase and invertase in winter oat: responses to second-phase cold hardening. Plant. Physiol. 116: 403-408.

PAUL M.J., COCKBURN W. 1989. Pinitol, a compatible solute in Mesembryanthemum crystallinum L. J. Exp. Bot. 40: 1093-1098 .

PEARSE A.G.E. 1972. Theoretical and applied histochemistry. Eds. Williams \&Wilkins, vol. 2. Baltimore.

PILON-SMITS E.A.H., EBSKAMP M.J.M., JEUKEN M.J.W., WEISBEEK P.J., SMEEKENS S.C.M. 1995. Improved performance of transgenic fructan-accumulating tobacco under drought stress. Plant. Physiol. 107: 125-130.

POLLOCK C.J., CAIRNS A.J. 1991. Fructan metabolism in grasses and cereals. Annu. Rev. Plant. Physiol. 42: 77-101.

POLLOCK C.J., CAIRNS A.J., COLLIS B.E., WALKER R.P. 1989. Direct effects of low temperature upon components of fructan metabolism in leaves of Lolium temulentum L. J. Plant. Physiol. 134: 203-208.

POPP M., LIED W., BIERBAUM U., GROSS M., GROßESCHULTE T., HAMS S., OLDENETTEL J., SCHÜLER S., WIESE J. 1997. Cyclitols-stable osmotica in trees. In: TreesContributions to Modern Trees Physiology, (ed.) Rennenberg H. 257-270.

RAKUSA-SUSZCZEWSKI S., MIĘTUS M., PIASECKI J. 1992. Pogoda i Klimat. In: Zatoka Admiralicji. Ekosystem przybrzeżnej morskiej antarktyki, (ed.) Rakusa-Suszczewski S. Dziekanów Leśny. Instytut Ekologii PAN 41-50 (in Polish).

REYNOLDS E.S. 1963. The use of lead citrate of high $\mathrm{pH}$ as an electron - opaque stain in electron microscopy. J. Cell. Biol. 17: 208-212.

SHIOMI N. 1989. Properties of fructosyltransferases involved in the synthesis of fructan in Liliaceous plants. J. Plant. Physiol. 134: 151-155.

SUZUKI M. 1989. Fructans in forage grasses with varying degrees of coldhardiness. J. Plant. Physiol. 134: 224-231.

VIJN I., VAN DIJKEN A., SPRENGER N., VAN DUN K., WEISBEEK P., WIEMKEN A., SMEEKENS S. 1997. Fructan of the inulin neoseries is synthesized in transgenic chicory plants (Cichorium intybus L.) harbouring onion (Allium cepa L.) fructan: fructan 6G fructosyltransferase. Plant. J. 11: 387-398.

WETTLAUFER S.H., LEOPOLD A.C. 1991. Relevance of Amadori and Maillard products to seed deterioration. Plant. Physiol. 97: 165-169.

YANCEY P.H., CLARK M.E., HAND S.C., BOWLUS R.D., SOMERO G.N. 1982. Living with water stress: evolution of osmolyte systems. Science 217: 1214-1222.

ZÚŃIGA G.E., ALBERDI M., CORCUERA L.J. 1996. Nonstructural carbohydrates in Deschampsia antarctica Desv. from South Shetland Islands, Maritime Antarctic. Envir. Exp. Bot. 4: 393-399.

ZÚŃIGA G.E., ALBERDI M.,FERNANDEZ J., MONTIEL P., CORCUERA L.J. 1994. Lipid content in leaves of Deschampsia antarctica from the Maritime Antarctic. Phytochem. 37: 669-672. 